\title{
PHYSIOLOGICAL AND BIOCHEMICAL CHANGES IN ALGAL CULTURES OF CHLORELLA VULGARIS AND SYNECHOCYSTIS SALINA (MESOPHILIC AND ANTARCTIC ISOLATES) OCCURING AFTER TREATMENT WITH UV-B RADIATION
}

\author{
Dilyana Doneva, Juliana Ivanova, Lyudmila Kabaivanova
}

\begin{abstract}
Determination of biomass production and viability of algal cells of Chlorella vulgaris and Synechocystis salina exposed to UV-B radiation were carried out in this study together with comparison of the mesophilic and antarctic isolates of both investigated strains. Estimation of the content of the pigments: chlorophyll $a$, chlorophyll $b, \beta-$ carotene, C-phycocyanin and allo-phycocyanin in algal cells exposed to UV-B radiation was also accomplished. The obtained results showed that the antarctic algae are more resistant to oxidative stress than their mesophilic counterparts. The antarctic isolates of Ch. vulgaris and S. salina compared with the mesophilic ones - up to $72 \mathrm{~h}$ showed tolerance to low exposures of radiation, expressed in a slight stimulation of growth and viability of the cells. Antarctic isolates also showed greater resistance to low doses of UV-B radiation manifested by stimulation of the synthesis of chlorophyll $a$ and $\beta$-carotene. The registered increase in the amount of $\mathrm{C}$ - and allo-phycocyanin in antarctic isolates of $S$. salina showed that they had developed protective strategies against UV-B radiation by increasing the concentration of the phycobiliproteins. As a result of increased UV-B background, in antarctic isolates, stronger antioxidant defence mechanisms are triggered, which proved the possibility of using them as markers of oxidative stress.
\end{abstract}

Key words: algae, antarctic isolates, UV-radiation, biochemical changes

\section{INTRODUCTION}

Algae are an extensive group of photosynthetic organisms distributed through a wide variety of habitats. They are the main support of the entire life. UV irradiation in lakes can affect photosynthesis of aquatic organisms down to a depth of 10-70 $\mathrm{m} \mathrm{[1].}$ Algae may develop numerous strategies to cope with UV radiation like multiple layered cell walls, absorbing compounds such as carotenoids, proteins and some reparing enzymes, that enable adaptation to environmental stress [2]. Recently a reduced concentration of ozone in the stratosphere was established over different latitudes and especially over Antarctica. The penetration of solar UV-B radiation $(280-315 \mathrm{~nm})$ to the earth surface compromise the flora and fauna and is becoming a global problem. Although UV-B radiation is a small component of the solar spectrum ( $<1 \%$ of energy) it is highly reactive and induces significant physiological, biochemical, genetic and structural damages to the plant cells due to the ensuing oxidative stress [3-7]. It is known that many of the ecotoxicological protective strategies of unicellular organisms function also in higher organisms, so the research on lower organisms would provide important information regarding evolutionary processes at a cellular level [3]. In comparison with the macrophytes, these organisms show more immediate sensitivity to even to slight increases in UV radiation. Therefore, microalgae and especially cyanobacteria (as the oldest producers of $\mathrm{O}_{2}$ on the planet) are included in numerous complex strategies as test organisms [8].

Investigating populations of microalgae and cyanobacteria under UV stress conditions is important concerning their role in ecosystems. They are involved in the primary production of biomass, biodiversity, as well as being sources of valuable natural products. However, studies of polar prokaryotic and eukaryotic algal species show that they are able to grow over a wide temperature range [9]. This psychrotrophic character, and the fact that their metabolism is similar to that of higher plants are also compelling arguments that Antarctic algae are reliable test subjects in solving problems arising from stressful situations in their habitats.

The study of the changes that occur in the concentration of biotechnologically valuable antioxidant pigments (C-phycocyanin, Allo-phycocyanin and $\beta$ carotene) in the algal cells exposed to UV stress deserves much attention. [10, 11].

The problem for the development of plant biomarker test systems is particularly relevant in a national and global scale in relation to strategies for protecting the genetic resources of crops, biodiversity and stability of the genome of plant populations (natural and cultural).

The objectives of this work were to study and compare the occurring physiological and biochemical changes in algal cultures of Chlorella vulgaris and Synechocystis salina (mesophilic and antractic isolates) after treatment with UV-B radiation as well 
as following the physiological responses manifested by alterations in the growth, vitality, content of photosynthetic pigments, total proteins and carbohydrates.

\section{MATERIALS AND METHODS}

Subjects of this study are antarctic and mesophilic isolates of the unicellular green alga Chlorella vulgaris Beyer (Chlorophyta) and unicellular cyanobacterium Synechocystis salina Wislouch. Antarctic cyanobacteria Synechocystis salina and green algae Chlorella vulgaris were isolated respectively from moss and soil samples collected on Livingston Island, South Shetland Islands. Mesophilic Synechocystis salina and Chlorella vulgaris were obtained from the collection of autotrophic organisms (CCALA) at the Institute of Botanics- Trebon.

Cultivation of studied cell lines was carried out intensively up to reaching of stationary phase of growth. For the two isolates of Chlorella vulgaris (antarctic and mesophilic) the nutrient broth of Setlik Simer was used, modifid by Georgiev et al. (1978) [12] with the following composition: $\mathrm{NH}_{4} \mathrm{NO}_{3}(0.4$ $\mathrm{g} / \mathrm{l}), \mathrm{CO}\left(\mathrm{NH}_{2}\right)_{2}(0.3 \mathrm{~g} / \mathrm{l}), \mathrm{MgSO}_{4} .7 \mathrm{H}_{2} \mathrm{O}(0.494 \mathrm{~g} / \mathrm{l})$, $\mathrm{KH}_{2} \mathrm{PO}_{4}(0.17 \mathrm{~g} / \mathrm{l}), \mathrm{NaHCO}_{3}(2.0 \mathrm{~g} / \mathrm{l})$, trace elements. Twice diluted medium of Pekárková et al. (1988) [13], containing: $\mathrm{KNO}_{3}(1.24 \mathrm{~g} / \mathrm{l}), \mathrm{K}_{2} \mathrm{HPO}_{4}(0.62 \mathrm{~g} / \mathrm{l})$, $\mathrm{MgSO}_{4} .7 \mathrm{H}_{2} \mathrm{O}(2.5 \mathrm{~g} / \mathrm{l}), \mathrm{KCl}(8.00 \mathrm{~g} / \mathrm{l}), \mathrm{NaCl}(6.26$ $\mathrm{g} / \mathrm{l}), \mathrm{KI}(0.50 \mathrm{~g} / \mathrm{l}), \mathrm{KBr}(0.50 \mathrm{~g} / \mathrm{l}), \mathrm{Ca}\left(\mathrm{NO}_{3}\right)_{2}(0.17 \mathrm{~g} / \mathrm{l})$, EDTA $(0.0093 \mathrm{~g} / \mathrm{l}), \mathrm{H}_{3} \mathrm{BO}_{3}(0.0015 \mathrm{~g} / \mathrm{l})$, trace elements; with added $\mathrm{NaNO}_{3}-1.26 \mathrm{~g} / 1, \mathrm{NaHCO}_{3}-3.0$ $\mathrm{g} / \mathrm{l}$ and $\mathrm{C}_{10} \mathrm{H}_{14} \mathrm{~N}_{2} \mathrm{O}_{8} .2 \mathrm{H}_{2} \mathrm{O}-0.20 \mathrm{~g} / \mathrm{l}$ was used for the cultivation of the mesophilc and antarctic isolate Synechocystis salina. Antarctic and mesophilic Chlorella vulgaris were cultivated at 26 and $31{ }^{\circ} \mathrm{C}$, while the two isolates of Synechocystis salina - at 25 and $31{ }^{\circ} \mathrm{C}$, respectively. The growth of algae is done in glass containers of $200 \mathrm{ml}$, illuminated surface of $140 \mathrm{~cm}^{2}$ with continuous lighting with fluorescent lamps with light intensity of $180 \mu \mathrm{mol} \mathrm{m} \mathrm{m}^{-2} \mathrm{~s}^{-1}$ and aeration of $100 \mathrm{l} \mathrm{m}^{-3} \mathrm{~h}^{-1}$ air enriched with $2 \% \mathrm{CO}_{2}$ [14].

For UV-B irradiation, two ultraviolet-B lamps (Philips TL 20W/12 RS SLV) with main output at $312 \mathrm{~nm}$ were used. A suspension culture from sterile $140 \mathrm{~mm}$ Petri dishes, occupying a depth of $0.5 \mathrm{~cm}$ was subjected to artificial UV-B irradiation $(280 \mathrm{~nm}$ to $315 \mathrm{~nm}, 1.5 \mathrm{~W} \cdot \mathrm{m}-2$ ) for $15 \mathrm{~min}, 30 \mathrm{~min}, 60 \mathrm{~min}$, and $240 \mathrm{~min}$. A magnetic stirrer gently agitated the suspension to ensure uniform exposure. The irradiance was measured using a power meter "OPHIR - Nova II Display Rohs" (Israel).
Algal growth was measured gravimetrically as absolutely dry weight in an oven at $105{ }^{\circ} \mathrm{C}$ for 20 hours. Absolute dry weight (DW) was measured on an analytical balance.

The viability of cells was determined by triphenyl tetrazolium chloride test. Two $\mathrm{ml}$ of the algal suspension was placed in centrifuge tubes. Centrifugation for $20 \mathrm{~min}$ at $4600 \mathrm{rpm}$ was performed, the supernatant is discarded and to the precipitated cells $5 \mathrm{ml}$ of $0.6 \%$ triphenyl tetrazolium chloride in $0,05 \mathrm{M} \mathrm{Na}_{2} \mathrm{PO}_{4}-\mathrm{KH}_{2} \mathrm{PO}_{4}$ buffer $\mathrm{pH}=7,4$ was added. Incubation was performed in a thermostat at $37^{\circ} \mathrm{C}$ for $18-20$ hours. After incubation the tubes are centrifuged and the supernatant discarded. The precipitated cells were mixed and poured with 2-3 ml of boiling $95 \%$ ethanol, and then placed for 5 minutes in a pre-boiled water bath. Water insoluble formazan is extracted most efficiently with ethanol and using this procedure $98 \%$ of the formazans are in the initiating extraction. After cooling the tubes were centrifuged and the supernatant was transferred to graduated test tubes, topped up with ethanol to $10 \mathrm{ml}$. The absorbance is measured on a spectrophotometer at $530 \mathrm{~nm}$ (Steponkus and Lanphear, 1967).

The pigments (chlorophyll $a$, chlorophyll $b, \beta-$ carotene) were determined after extraction with methanol. The determination is carried out according to the absorption spectra on a spectrophotometer at 665, 650 and $460 \mathrm{~nm}$. Calculations are made according to the formulas of Mc Kinny [16].

C-phycocyanin is isolated and purified by the method of Minkova et al. (2007). Fresh algal biomass ( $800 \mathrm{mg}$ dry weight) was rinsed with extraction buffer $\left(0.01 \mathrm{M} \mathrm{KH}_{2} \mathrm{PO}_{4} / \mathrm{K}_{2} \mathrm{HPO}_{4}\right.$, $\mathrm{pH}$ 6.7), resuspended in $100 \mathrm{ml}$ of the same buffer, frozen at $-15{ }^{\circ} \mathrm{C}$, thawed and heated at $30{ }^{\circ} \mathrm{C}$ for $1 \mathrm{~h}$ under continuous stirring, and left at $4{ }^{\circ} \mathrm{C}$ overnight. The suspension was centrifuged at $18000 \mathrm{~g}$ for $30 \mathrm{~min}$ and the supernatant was considered as a crude extract. The crude extract $(100 \mathrm{ml})$ was mixed with $10 \mathrm{ml} 0.3 \%(\mathrm{w} / \mathrm{v})$ aqueous rivanol (6,9-diamino-2ethoxyacridine lactate, Sigma) solution, left at $4{ }^{\circ} \mathrm{C}$ overnight and centrifuged (step I). This and all subsequent centrifugations were carried out at 8000 $\mathrm{g}$ for $30 \mathrm{~min}$. The supernatant was subjected to a second rivanol treatment (step II) as described in step I. The supernatant was saturated up to $40 \%$ $(\mathrm{v} / \mathrm{v})$ with ammonium sulfate and centrifuged. The precipitate was dissolved in $25 \mathrm{ml}$ of extraction buffer and centrifuged. To remove the rivanol, the solution was applied on a Sephadex G-25 (coarse) column $(50.0 \mathrm{~cm} \times 2.0 \mathrm{~cm})$ pre-equilibrated and eluted with the same extraction buffer (step III). The 
blue eluate was saturated to $70 \%$ (v/v) with ammonium sulfate and centrifuged. The precipitate was dissolved in $20 \mathrm{ml}$ of extraction buffer and after subsequent centrifugation the C-phycocyanin-rich solution was obtained (step IV). [17]. The content of $\mathrm{C}$ - and allo-phycocyanin was calculated by the equations described by Siegelmann and Kycia [18].

\section{RESULTS AND DISCUSSION}

Biomass production and viability of algal cells exposed to UV-B radiation was followed, as well as the comparison between the antarctic and mesophilic isolates of Chlorella vulgaris (Fig. $1 \mathrm{~A}, \mathrm{~B}$ ).
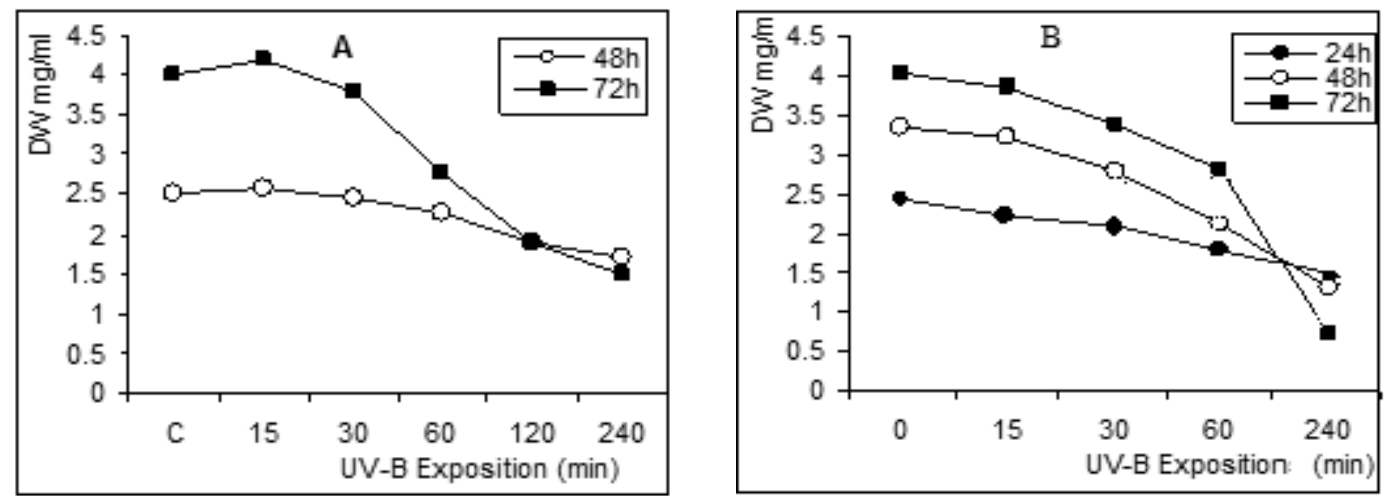

Fig. 1. Growth of Chlorella vulgaris after irradiation with UV-B as a consequence of $48 \mathrm{~h}$ and $72 \mathrm{~h}$ of cultivation, (A) - antarctic, (B) - mesophilic

The results show that the antarctic isolate $C h$. vulgaris, compared with the mesophile up to $72 \mathrm{~h}$ showed tolerance to short exposures to radiation, expressed in a slight growth stimulation (Fig. 1 B). The mesophilic analogue was more sensitive even to the shortest exposures and they lead to suppression of biomass synthesis (Fig. 1B). This finding was confirmed by the vitality of cells (Fig.
3). In the antarctic Ch. vulgaris after slight irradiation (15 min) a slight increase in cell viability was recorded (Fig. 3 A), while in the mesophilic viability decreased at all applied durations of radiation (Fig. 3 B). Figure 2 shows the cells of both investigated strains after application of UV-B radiation estimated by triphenyl tetrazolium chloride test.
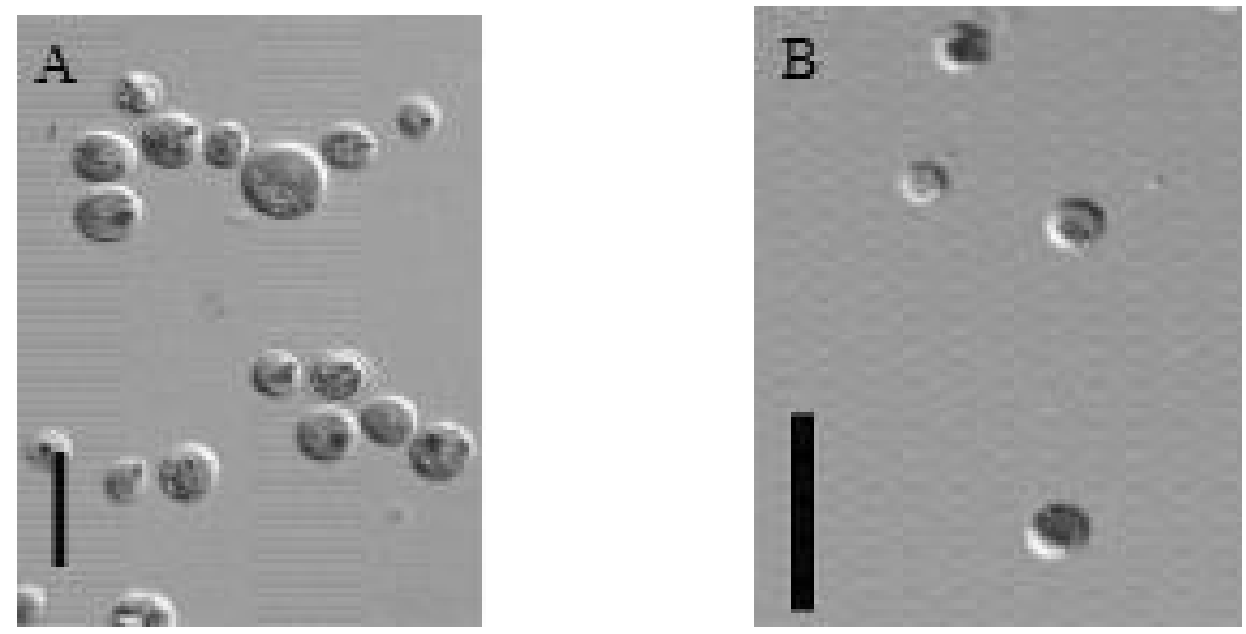

Fig. 2. Light microscopy images showing determination of the viability of both (A) Chlorella vulgaris and (B) Synechocystis salina after application of UV-B radiation by Triphenyl tetrazolium chloride test. The red formazan crystals are as a result from the enzymatic reactions indicative of a high vitality. 

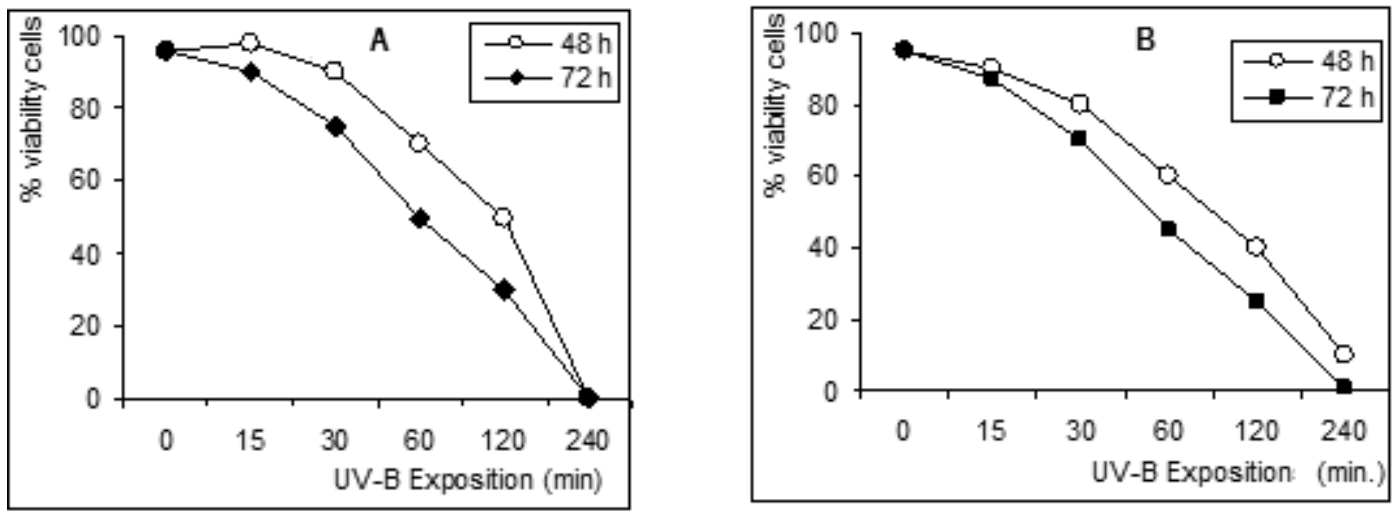

Fig. 3. Viability of Chlorella vulgaris after irradiation with UV-B-as at $48 \mathrm{~h}$ and $72 \mathrm{~h}$ of cultivation, (A) antarctic and (B) - mesophilic.

The results shown in Fig. 4 (A, B) indicate that the antarctic isolate of $S$. salina reacted with an enhanced growth after short-term exposure to UV-B stimulation which is maintained until $72 \mathrm{~h}$ of cultivation under optimal conditions. The long-term (30 $\mathrm{min})$ exposure lead to strong inhibition of the synthesis of biomass. In comparison with the antarctic cyanobacterium, the mesophilic one was more sensitive to UV-B radiation and reacted with inhibition of growth even at the weakest irradiation (15 min) (Fig. 4 A, B).

The vitality of the cells responded adequately to the growth curve. In the antarctic isolate of $S$. salina low UV-BR exposures caused a slight increase (3\%) of the cell viability. In the mesophilic cyanobacterium viability began to decrease further after 15 min exposure (Fig. 5 A, B).

The antarctic isolates of Ch. vulgaris and $S$. salina compared with the mesophilic ones - up to 72 $\mathrm{h}$ showed tolerance to low exposures of radiation, expressed in a slight stimulation of growth and viability of the cells.

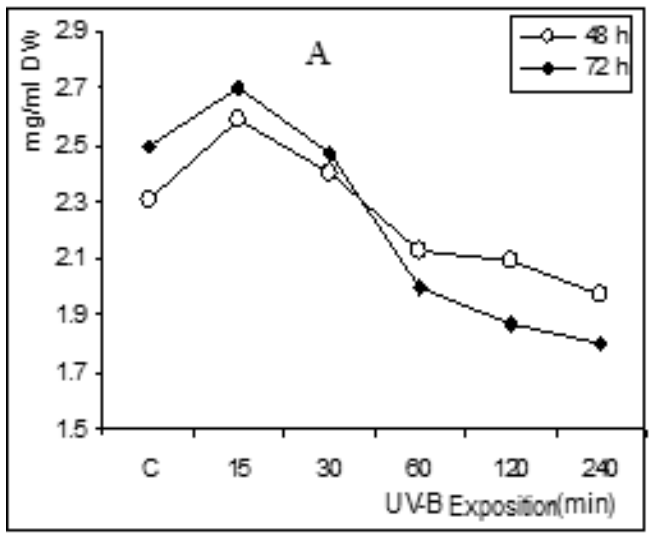

Changes in the pigment content - chlorophyll $a$, chlorophyll $b, \beta$-carotene, C-phycocyanin and allophycocyanin in the cells of antarctic and mesophilic isolates of Chlorella vulgaris and Synechocystis salina exposed to UV-B irradiation were estimated. Short term (15 min) UV-B irradiation of cells of antarctic $C h$. vulgaris and $S$. salina lead to increasing the amount of chlorophyll $a$ with $24 \%$ and $\beta$-carotene with $8,3 \%$ (Fig. 6 A, Fig. 7 A ). Meanwhile, mesophilic analogues reacted with a decrease in chlorophyll content in all tested exposures

(Fig.6 B and Fig. 7 B). The content of carotens increased at short exposures, in the antarctic as well as in the mesophilic analogues of cyanobacteria and green microalgae. In the antarctic $S$. salina, however, the content of $\beta$-carotene increased twice compared to the increase recorded for the mesophilic strain. Thus, the increase of $\beta$-carotene for antarctic $S$. salina was $37,5 \%$ with respect to the control, and in the mesophile - $17.9 \%$ (Fig. 7, Fig. 9).

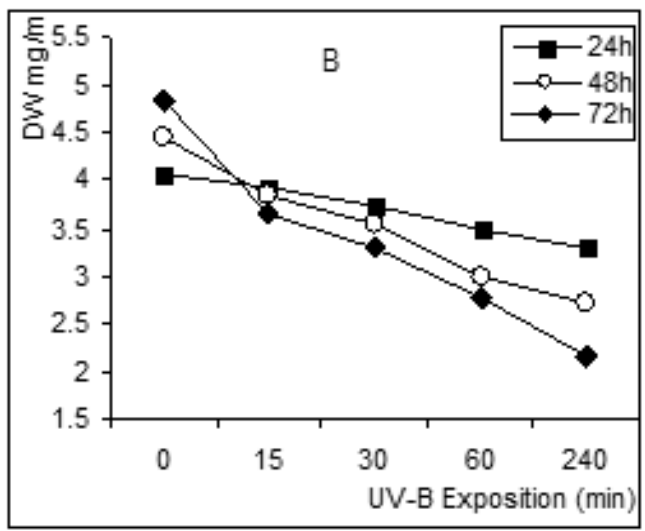

Fig. 4. Growth of S. salina, $48 \mathrm{~h}$ and $72 \mathrm{~h}$ after treatment with UV-B. (A)-antarctic, (B)-mesophilic isolate. 

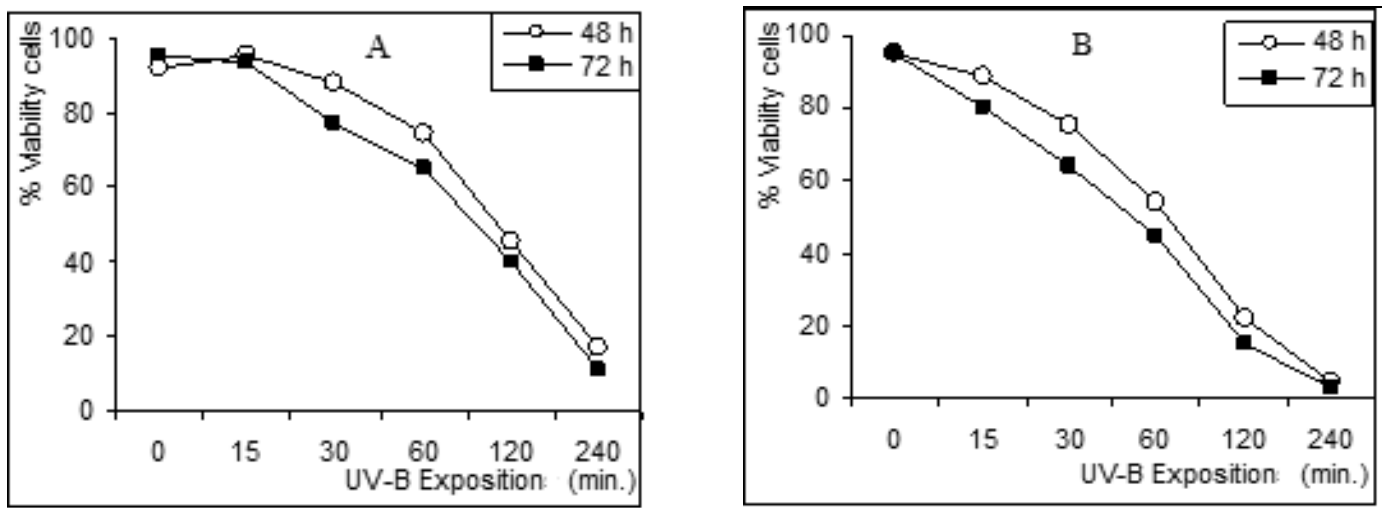

Fig. 5. Vitality of S. salina $48 \mathrm{~h}$ and $72 \mathrm{~h}$ after irradiation with UV-B. (A) - antarctic, (B) - mesophilic isolate

Chlorophyll content can be an indicator in assessing the sensitivity to UV-B stress. Antarctic isolates showed greater resistance to low doses of UV-BR, manifested by stimulation of the synthesis of chlorophyll $a$ and $\beta$-carotene. An elevated concentration of carotene in the cases of tolerable oxidative stress caused by UV-BR, in the antarctic as well as in mesophilic isolates proved the possibility these pigments to be regarded as markers, non-enzymatic antioxidant protectors.
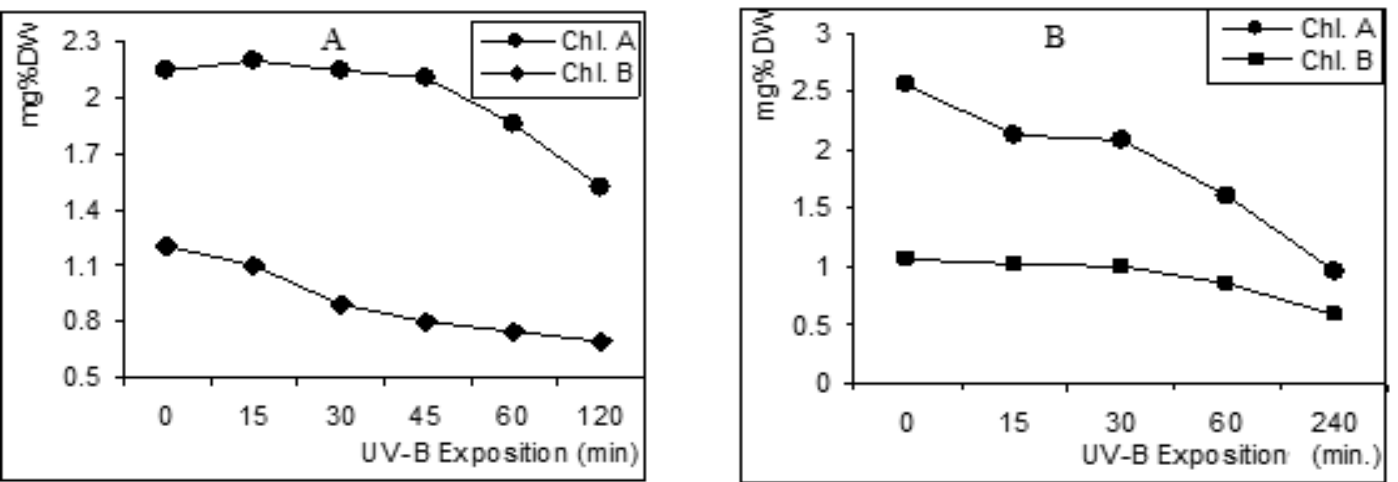

Fig. 6. Effects of UV-B irradiation on Ch. vulgaris chlorophyll $a$ and chlorophyll $b$ content after $48 \mathrm{~h}$.

Cultivation under optimum conditions (A) - antarctic, (B) - mesophilic isolate.
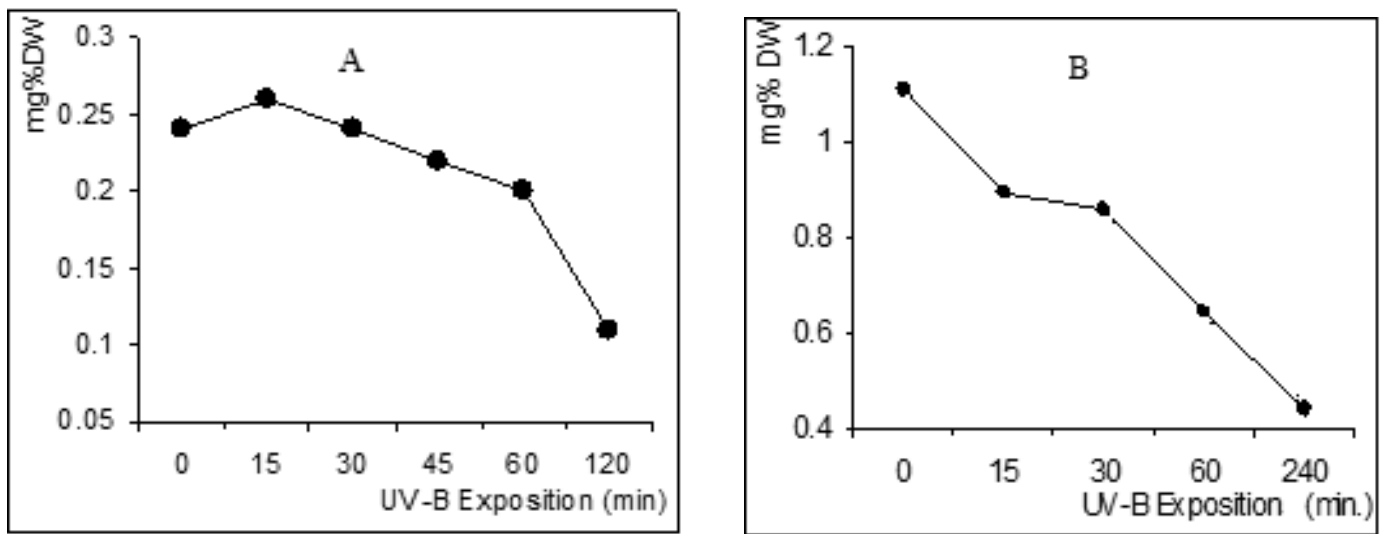

Fig. 7. Effects of UV-B irradiation on Ch. vulgaris $\beta$-carotene content after 48 h. Cultivation under optimum conditions (A) - antarctic, (B) - mesophilic isolate. 

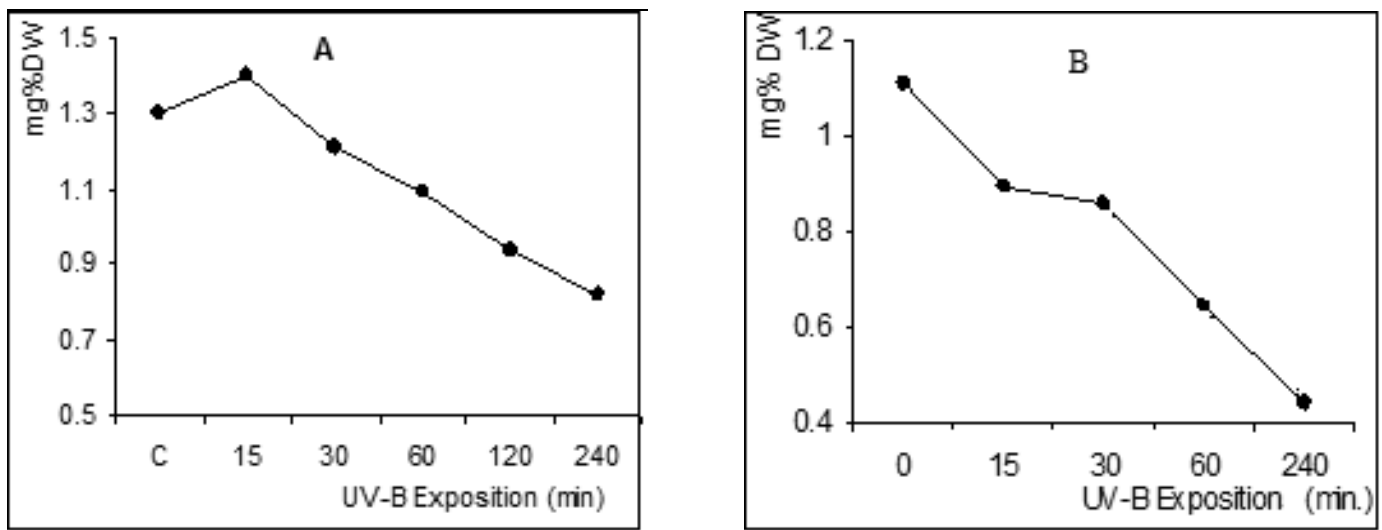

Fig. 8. Effect of UV-B irradiation on S. salina chlorophyll a content after $48 \mathrm{~h}$. Cultivation under optimum conditions. (A) - antarctic, (B) - mesophilic isolate.
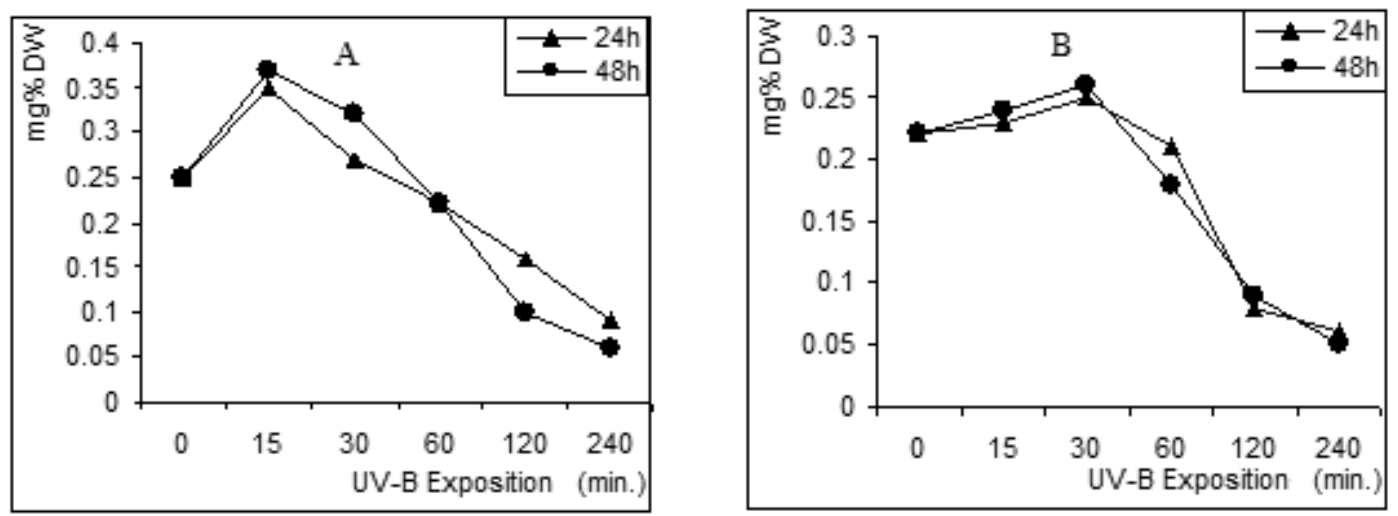

Fig. 9. Effects of UV-B irradiation on $S$. salina $\beta$-carotene content after $48 \mathrm{~h}$ cultivation under optimum conditions (A) - antarctic, (B) - mesophilic isolate.

Comparable study of the dynamic changes in the content of phycobiliproteins after UV-BR in the biomass of antarctic and mesophilic isolates of the cyanobacterium S. salina showed that short exposures increased the C-phycocyanin and allophycocyanin. At the same time the mesophilic isolate reacted with their reduction at all investigated exposures (Fig. 10, Fig. 11).
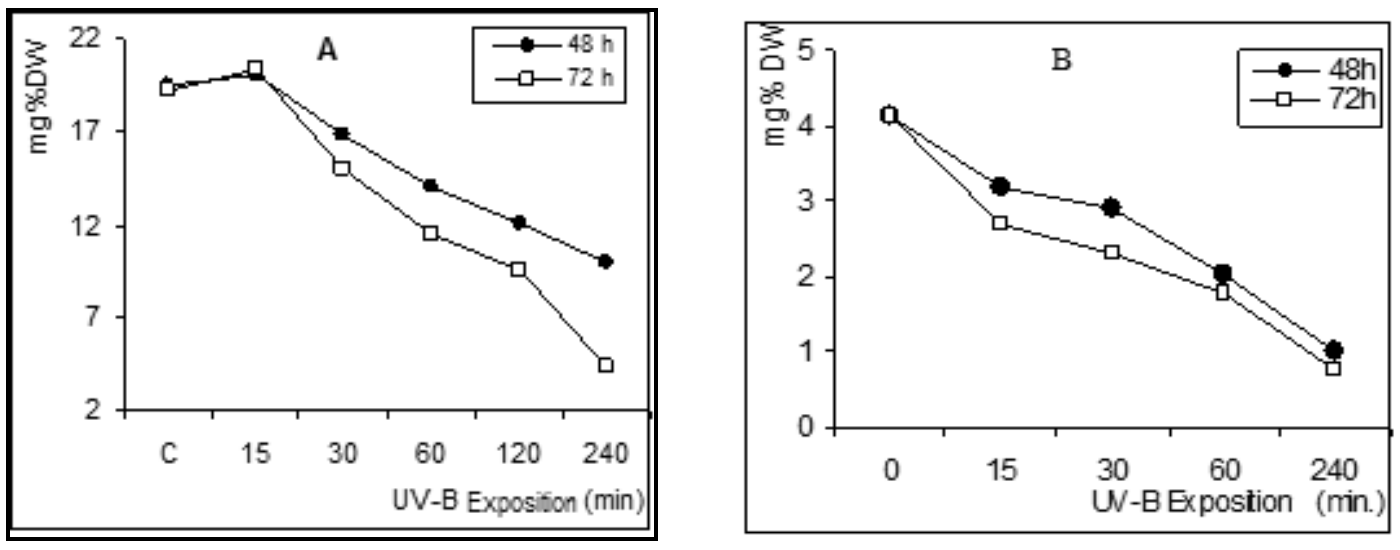

Fig. 10. Content of C-phycocyanin in the biomass of $S$. salina after irradiation with UV-B after $48 \mathrm{~h}$ and $72 \mathrm{~h}$ (A) - antarctic, (B) - mesophilic isolate. 

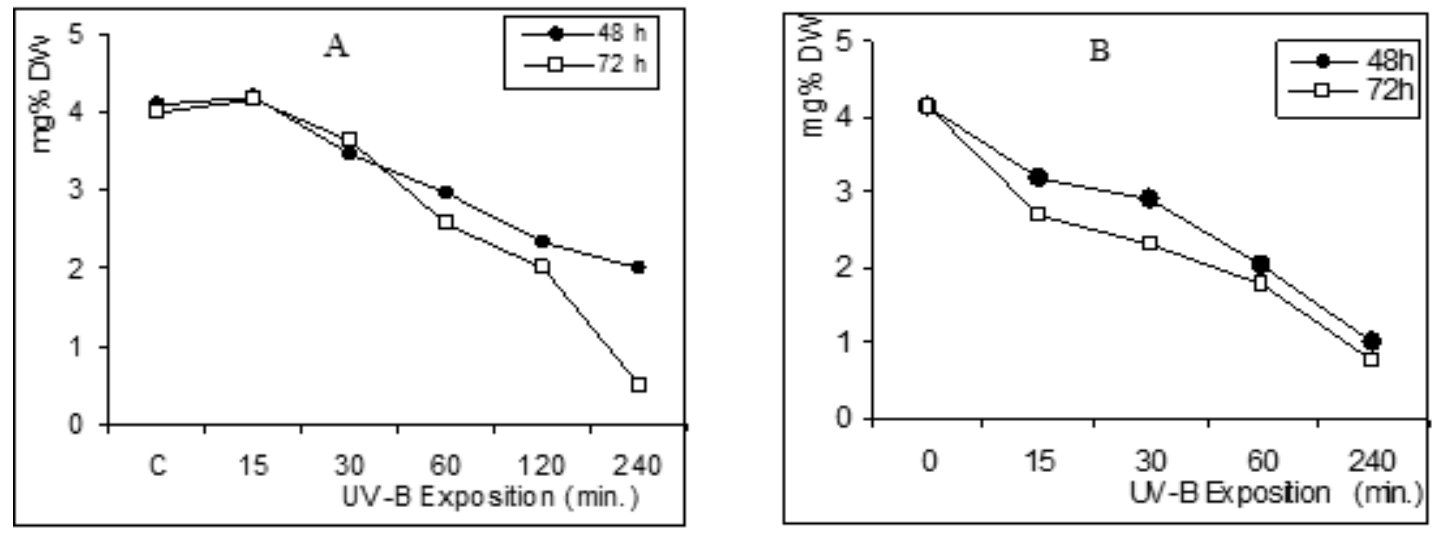

Fig. 11. Contents of Allo-phycocyanin in biomass of $S$. salina after irradiation with UV-B after $48 \mathrm{~h}$ and $72 \mathrm{~h}$ (A) - antarctic, (B) - mesophilic isolate.

In the antarctic isolates of $S$. salina, brief exposure to UV-B radiation lead to an increase in the amount of C-phycocyanin and allophycocyanine. This indicates that the antarctic strains have developed protective strategies against UV-BR by increasing the concentration of the phycobiliproteins. In Antarctic cyanobacteria, phycobiliproteins can be identified as sensitive and fast responsive markers of oxidative stress that could also activate the antioxidant defense mechanisms.

The synthesis of microalgal biomass in different habitats with different conditions is essential as algae contribute to the primary production of biomass in these areas. UV-B radiation with high intensity significantly inhibited the growth of Antarctic phytoplankton [19]. UV-BR results in a decrease of photosynthesis and photosynthetic pigments, a circumstance, which reflects in synthesis of a less amount of biomass $[19,20]$. The effect of UV-B on economically important red macroalgae also leads to a reduction in vitality [21]. Meanwhile, tetraspores of Irideae cordata show good tolerance to UV radiation [22], from which follows that the resistance to UV radiation is species specific, and is influenced by the ontogenetic stage of affected algal organism.

The study of antarctic algae that are under increased UV radiation, as models of survival are logically motivated [23] as the unicellular green algae, particularly cyanobacteria, are extremely resistant to the action of different extreme environmental conditions. In antarctic green algae and cyanobacteria, increased UV radiation leads to an overall reduction in photosynthesis $[24,5]$. Studies with endemic antarctic algae of the genus Palmaria showed that photosynthetic activity and pigment content depends on the length of exposure to visible light [25]. After investigations on antarctic plankton it was suggested that the established resistance to UV radiation is probably due to protection from the contained in algae phycoerythrin [26] and phycocyanin [27]. According to our results, blue-green algae $S$. salina showed better adaptation by increased growth at short exposures. The same authors indicate that photosynthetic microorganisms habitats exposed to high UV stress, have developed a strategy for survival through changes in the primary (chlorophylls) and secondary (phycocyanins) photosynthetic pigments, and they are typical biomarkers for UV screening. Under UV$\mathrm{B}$ effects it was considered that the phycobilisome in which phycobiliproteins are concentrated, play an important role in photoprotection. On the other hand they capture light that chlorophyll $a$ can not adsorb and deliver it to Photosystem II [11]. As an expression of a defense mechanism for the recovery of cells Lyngbia estuarii, subjected to enhanced UV radiation progressively increased content of $\beta$ carotenes is recorded [28]. Achieved in this way protection is due to the screening functions of these pigments, free radical scavenging [29].

The behaviour of photosynthetic pigments depends on the dose of radiation. So for Chlorella $s p$. it has been found that UV-B radiation at lower doses increases the photosynthetic pigment chlorophyll $a$ and carotenoid content, while at higher doses their values decrease [30]. Our findings for the increase in the content of carotenoids can be explained by the fact that they are the most prominent antioxidants among lipophilic compounds. They cause accumulation of singlet oxygen through the suppression of the energy as heat [31]. Moreover carotenoids protect Photosystem II from photoinhibition [32]. Cells of 
Chlorella sp., affected by low dose UV-B radiation increase $\beta$-caroten content, and at higher doses it reduces [30].

Similar to our findings about the reduction of the content of phycobiliproteins in cells of $S$. salina after UV-B radiation, a number of authors reported a similar reaction in other cyanobacteria and representatives of Rhodophyta [20].

\section{CONCLUSIONS}

Antarctic algae are more resistant to oxidative stress than their mesophilic counterparts. In a comparative study the effect of UV-B radiation on the behavior of pigments in the antarctic and mesophilic cyanobacterium $S$. salina was found that the antarctic cyanobacteria respond with an increase in the content of $\mathrm{c}$ - and allo-phycocyanins, chlorophyll $a$ and $\beta$-carotene at the lowest UV-B exposure (15 min.). This is evidence that as a result of increased UV-B background in antarctic isolates stronger antioxidant defence mechanisms are triggered, which proved the possibility of using them as markers of oxidative stress. Detailed clarification of the effects of UV-B radiation on living organisms, in particular plants is a topic issue and represents a wide field of research related to biodiversity conservation and environmental protection.

\section{REFERENCES}

1. Holzinger A. and C. Lütz, Algae and UV irradiation: Effects on ultrastructure and related metabolic functions, Micron, Vol. 37, 2006, 190-207.

2. Pessoa M., J. Emir, Harmful effects of UV radiation in Algae and aquatic macrophytes. A review, Food Agric., Vol.24 (6), 2012, 510-526.

3. Xue L., S. Li, H. Sheng, H. Feng, S. Xu, L. An, Nitric oxide alleviates oxidative damage induced by enhanced ultraviolet-B radiation in cyanobacterium. Curr. Microbiol., Vol.55, 2007, 294-301.

4. Viñegla B., M. Segovia, F. L. Figueroa, Effect of artificial UV radiation on carbon and nitrogen metabolism in the macroalgae Fucus spiralis L. and Ulya oliyascens Dangeard. Hydrobiol., Vol. 560, 2006, 1-42.

5. Lesser M. P., Effects of ultraviolet radiation on productivity and nitrogen fixation in the Cyanobacterium, Anabaena sp. (Newton's strain). Hydrobiol., Vol.598, 2008, 1-9.

6. Apostolova E. L., A. G. Dobrikova, P. I. Ivanova, I. B. Petkanchin, S. G. Taneva, Relationship between the organization of the PSII supercomplex and the functions of the photosynthetic apparatus. J. Photochem. Photobiol. B: Biology, Vol. 83, 2006, 114-122.

7. Rastogi R. P., S. P. Singh, D. P. Häder and R. P. Sinha, Ultraviolet-B-induced DNA damage and photorepair in the cyanobacterium Anabaena variabilis PCC 7937. Env. Exp. Bot., Vol.74, 2011, 280-288.

8. Castenholz R., Cellular origin and life in extreme habitats and astrobiology. Ed. J. Secbach, Springer Nederlands, Vol.6, 2004, 444-461.

9. Vona V., V.D.M. Rigano, O. Lobosko, S. Carfagna, S. Esposito, C. Rigano, Temperature responses of growth photosynthesis, respiration and NADH: nitrate reduktase in cryophilic and mesophilic algae, N. Phytol., Vol.163, 2004, 325331.

10. Schmidt É. C., B. Pereira, R. W. dos Santos et al., Responses of the macroalgae Hypnea musciformis after in vitro exposure to UV-B, Aquat. Bot., Vol.100, 2012, 8-17.

11. Xue L., Y. Zhang, T. Zhang, L. An X. Wang, Effects of Enhanced Ultraviolet-B Radiation on Algae and Cyanobacteria, Critical Rev. Microbiol. Vol.31, 2005, 79-89.

12. Georgiev, D., C. Dilov, S. Avramova, Buffer nutrient medium and a method for intensive cultivation of green microalgae. Hidrobiologia, Vol.7, 1978, 14-24.

13. Pekarkova, B., F. Hindak, J. Smarda, Morphological characteristics and physiological properties of coccoid rhodophycean alga Rhodella grizea from termal springs at Piestany, Czechoslovakia, Arch. Protistkd., Vol.135, 1989, 69-83.

14. Дилов, Х., Микроводорасли- масово култивиране и приложения , Изд. БАН, 1985, 194 стр.

15. Steponcus, P. L., F. O. Lanphear, Refinement of the tryphenyl tetrazolium chloride method of determining cold injury, Plant Physiol. Vol.42, 1967, $1423-1426$.

16. Mc Kinny G., Criteria for purity of chlorophyll preparations. J. Biol. Chem., Vol.132, 1941, 91-96.

17 Minkova, K., L. Gigova, A. Tchernov, M. Stojanova, N. Ivanova, R. Boteva, M. Tchorbadjieva, Isolation of pure C-phycocyanin from Arthrospira maxima and Arthrospira fusiformis by a modified non-chromatographic rivanol sulfate procedure, Compt. Rend. Acad. Bulg. Sci., Vol. 60, 7, 2007, 795-798.

18. Siegelman HW, J.H. Kycia, Algal biliproteins. In: Hellebust JA, Craigie JS (eds) 
Handbook of Phycological Methods, Physiological and Biochemical Methods, Cambridge University Press, Cambridge, 1978, 71-79p.

19. Wang Q., Y. Hou, J-I. Miao, Effect of UV-B radiation on the growth and antioxidant enzymes of Antarctic sea ice microalgae Chlamydomonas sp. ICE-L. Acta Physiol. Plant., Vol.31, 2009, 1097 1102 .

20. Bhandari R., P. K. Sharma, Photosynthetic and biochemical characterization of pigments and UV-absorbing compounds in Phormidium tenue due to UV-B radiation, J. Appl. Phycol., Vol. 23, 2011, 283-292.

21. Schmidt E. C., M. Maraschin, Z. L. Bouzon, Effects of UVB radiation on the carragenophyte Kappaphycus alvarezii (Rhodophyta, Gigartinales): changes in ultrastructure, growth, and photosynthetic pigments, Hydrobiologia, Vol. 649, 2010, 171-182.

22. Zacher K., M. Y. Roleda, A. Wilff, D. Hanelt, C. Wiencke, Responses of Antarctic Iridaea cordata (Rhodophyta) tetrapores ezposed to ultraviolet radiation, Physiol. Res., Vol.57,3, 2009, 186-193.

23. Pattanaik, B., M. Roleda, R. Schumann, U. Karsten 2008. Isolate-specific of ultraviolet radiation on photosynthesis, growth and mycosporine-like amino acids in the microbial mat-forming cyanobacterium Microcoleus chethonoplastes. Planta. 227, 4, 907-16.

24. Rautenberger, R., K. Bischof, Impact of temperature on UV-susceptibility of two Ulva (Chlorophyta) species from Antarctic and
Subantarctic regions, Polar Biol., Vol.29, 2006, 988996.

25. Lüder, U. H., J. Knoetzel, C. Wiencke, Acclimation of photosynthesis and pigments to seasonally changing light conditions in the endemic Antarctic red macroalga Palmaria decipiens. Polar Biol., Vol.24, 2001, 598-603.

26. Martinez, R., Effects of ultraviolet radiation on protein content, respiratory electron transport system (ETS) activity and superoxide dismutase (SOD) activity of Antarctic plankton, Polar Biol., Vol.30, 2007, 1159-1172.

27. Wynn-Williams, D.D., H.G.M. Edwards, E.M. Newton, J.M. Holder, Pigmentation as a survival strategy for ancient and modern photosynthetic microbes under high ultraviolet stress on planetary surfaces. - Intern. J. Astrobiology.Vol. 1, 2002, 39-49.

28. Rath, J., P. S., Adhikary, Response of the estuarine cyanobacterium Lyngbya aestuarii to UV-B radiation, J. Appl. Phycol., Vol.19, 2007, 529-536.

29. Tang, E.Y., W. F. Vincent, Strategies of thermal adaptation by high-latitude cyanobacteria. New Phytol., Vol. 142, 1999, 315-323.

30. Juan Y., T. Xuexi, Z. Peiyu, T. Jiyuan, D. Shuanglin, Physiological and ultrastructural changes of Chlorella sp. Induced by UV-B radiation. Progress in Nat. Science, Vol.15, 8, 2005, 678 -683.

31. Frank H. A., R. J. Cogdell, Photochemistry and Photobiology, Vol.63, 7, 1996, 257 - 264.

32. Niyogi K. K., Ann. Rev. Plant Physiol. Plant Molecu. Biol. Vol.50, 1999, 333-359.

\title{
ФИЗИОЛОГИЧНИ И БИОХИМИЧНИ ПРОМЕНИ В КУЛТУРИ ОТ ВОДОРАСЛИ CHLORELLA VULGARIS И SYNECHOCYSTIS SALINA (МЕЗОФИЛНИ И АНТАРКТИЧЕСКИ ИЗОЛАТИ) НАСТЫПВАЩИ СЛЕД ПРИЛАГАНЕ НА UV-В ИЗЛЬЧВАНЕ
}

\author{
Диляна Донева, Юлияна Иванова, Людмила Кабаиванова
}

РЕЗЮМЕ. В настоящотосе изследване е извършено пределяне продукцията на биомаса и жизнеспособност на водораслови клетки на Chlorella vulgaris и Synechocystis salina подложени на UV-B радиация, заедно със сравняване на мезофилните и антарктически изолати на двата изследвани щама. Определено е съдържанието на пигментите: хлорофил $a$, хлорофил $\sigma, \beta$-каротин, Сфикоцианин и ало-фикоцианин във водораслите, след UV-B радиация. Получените резултати показват, че антарктическите водорасли са по-устойчиви на оксидативен стрес, отколкото съответните им мезофилни изолати. Антарктическите изолати от Ch. vulgaris и S. Salina в сравнение с мезофилните - до 72 час показват толерантност към ниски експозиции на радиация, изразена в леко стимулиране на растежа и жизнеспособността на клетките. Антарктическите изолати показват също по-голяма устойчивост на ниски дози от UV-B радиация, проявена чрез стимулиране на синтеза на хлорофил $a$ и $\beta$-каротин. Регистрираното увеличаване на количеството на С- и ало-фикоцианин в антарктическите изолати на S. Salina показа, че те са развили защитни стратегии срещу UV-B 
радиация чрез увеличаване на концентрацията на фикобилипротеини. В резултат на повишен фон на UV-B при антарктическите изолати се задействат силни антиоксидант защитни механизми, което доказва възможността за използването им като маркери на оксидативен стрес.

Ключови думи: водорасли, антарктически изолати, UV-облъчване, биохимични промени

\section{Dilyana Doneva, 'Assist. Prof. PhD}

Institute of Plant Physiology and Genetics, Department Experimental algology,

Bulgarian Academy of Sciences, email:did4e 7788@mail.bg

\section{Juliana Ivanova, Assist. Prof. PhD}

Institute of Plant Physiology and Genetics, Department Experimental algology,

Bulgarian Academy of Sciences, email:juivanova@yahoo.com

\section{Lyudmila Kabaivanova, Assoc. Prof., PhD}

The Stephan Angeloff Institute of Microbiology, Department Applied Microbiology,

Bulgarian Academy of Sciences, email: 1kabaivanova@yahoo.com 